\title{
Chiluria in a lymphatic filariasis endemic area
}

\author{
Paulo Sérgio Ramos de Araújo ${ }^{1,2^{*}}$, Valter Romão de Souza Junior ${ }^{1} \mathbb{B}$, Anderson de Souza ${ }^{1}$, \\ Luciana de Barros Correia Fontes ${ }^{1}$, Eduardo Brandao ${ }^{2}$ and Abraham Rocha $^{2}$
}

\begin{abstract}
Objective: To establish clinical and laboratory data of individuals presenting chyluria in endemic areas.

Results: 75 individuals were studied. The majority were females with an average age of 45 years residing in the Metropolitan Region of Recife. The mean time between the beginning of the presentation of chyluria and the first care service in the Serviço de Referencia Nacional em Filarioses was approximately 5 years. The most frequent urinalysis changes were hematuria (27.6\%), leukocytes (21.9\%) and proteinuria (10.5\%). The Addis test showed mean values of $155.43 \mathrm{E} / \mathrm{min} / \mathrm{mL}$ of cylinders, $52,892 \mathrm{E} / \mathrm{min} / \mathrm{mL}$ of erythrocytes and $291,660 \mathrm{E} / \mathrm{min} / \mathrm{mL}$ of leukocytes. Among recorded cases, proteinuria had a mean value of $1372.80 \mathrm{mg} / \mathrm{dL}$ in $24 \mathrm{~h}$, and the presence of lymphocytes in the urine was positive in $68.3 \%$. Among lymphatic filariasis tests, immunochromatography was positive in $16.7 \%$, there was circulating filarial antigen determined by detection of OG4C3 antibodies in 7.7\% and microfilaremia in only 1/55.
\end{abstract}

Keywords: Chyluria, Lymphatic filariasis, Wuchereria bancrofti

\section{Introduction}

Lymphatic filariasis (LF), also known as elephantiasis, occurs through infection by Brugia malayi, Brugia timori and Wuchereria bancrofti $[1,2]$. It has been considered a neglected disease, responsible for permanent or longterm physical disabilities in more than 40 million people, a considerable portion of a total of 120 million people infected worldwide [3, 4]. Endemic in 72 subtropical and tropical countries, it is estimated that there are 947 million individuals at risk of infection in 54 countries [5-7].

Currently, according to the Pan American Health Organization, there are 720,000 infected people in the American continent, distributed in Guyana, Dominican Republic and Haiti, and 9 million people living in areas with a risk of contamination [8]. In Brazil, there is no record of new autochthonous cases of MCF since 2014, causing the Ministry of Health to start a program of verification and elimination of LF, aiming the interruption of its transmission [9].

\footnotetext{
*Correspondence: psergiora@gmail.com

${ }^{1}$ Federal University of Pernambuco, Av. Prof. Moraes Rego 1235, Recife, Pernambuco 50670-901, Brazil

Full list of author information is available at the end of the article
}

Adult worms of Wuchereria bancrofti prefer the lymphatic system, where they are able to live from 4 to 8 years [10]. Despite a tropism through lymphatic vessels, the pathogenesis of the damage is still not completely clear. It is known, however, that the presence of adult worms in vessels and lymph nodes, mainly in the pelvic region (legs and scrotum), breasts and arms, causes damage to these structures, leading to lymphedema, hydrocele, keruria and elephantiasis [11-13]. Although it occurs in other clinical conditions, lymphatic fistulation syndromes (lichen, kilocele, and lymphocele) are considered strongly associated with this pathology in endemic areas of LF.

Chyluria, or milky urine, is the presence of pylorus in the urine, a fluid composed of lymph and chylomicrons absorbed by lymphatic vessels, transported to the thoracic duct and then drained into the subclavian vein. Normally, lymphatic vessels do not communicate with the urinary tract. When this occurs, the chylium escapes into the urine, and the point of leakage may occur in the kidney, ureter or bladder. The urine then acquires a characteristically milky coloration $[14,15]$.

It is believed that approximately $2-10 \%$ of individuals with LF develop chyluria, which is the main parasitic 
etiology of this clinical finding [16-18]. Chyluria generally occurs several years after infection by Wuchereria bancrofti and is characteristically intermittent [19]. As it causes protein loss, its association with asthenia, weight loss and malnutrition is common [20].

\section{Main text \\ Methods \\ Study area, population and study design}

A retrospective study was carried out, based on data recorded in the records of the National Reference Service in Filariasis of the Aggeu Magalhães Research Center (CPqAM), a unit of the Oswaldo Cruz Foundation (Fiocruz) in the State of Pernambuco, Recife, northeast of Brazil. This service meets the demands of all regions of the country.

There was respect for the universal principles of Human Rights and Bioethics in Research. The project was previously approved by Ethics Committee of Instituto Aggeu Magalhaes. It was considered a census sample of medical records of patients seen between 1996 and 2016.

In the analysis of the data, measurements of central tendency, dispersion measures and statistical tests were obtained, adopting a sampling error of $5 \%$, with the aid of the software Statistical Package for the Social Sciences (SPSS), version 23. The Chi square test, Student's $t$ test, and Fisher's exact test were used to cross-analyze the variables: gender, 24-h Proteinuria, Leukocytes, Casts, and Blood Cells.

\section{Results}

Among the 75 individuals studied, the majority were females $(45 / 75,60 \%)$, with a mean age of 45.2 years (minimum age of 14 and maximum age of 78 years). The majority (94.7\%) lived in the Metropolitan Region of Recife (MRR). In descending order, participants lived in Recife (34 cases, 45.4\%), Jaboatão dos Guararapes (13, 17.3\%), Olinda (11, 14.7\%), Paulista (9, 12\%), Camaragibe (2, 2.7\%), Cabo de Santo Agostinho (1, 1.3\%) and São Lourenço da Mata (1, 1.3\%). Among the cities in the countryside of Pernambuco, Vitória de Santo Antão, Caruaru and Riacho das Almas contributed with two (2.7\%), one (1.3\%) and one (1.3\%) cases, respectively. (Table 1).

The time elapsed between the first episode of chyluria and the first care service in the SRNF was on average 74.5 months (minimum time of 1 month and maximum of 456 months). Among the changes in urinalysis most frequently found in medical records, hematuria (27.6\%), leukocyte $(21.9 \%)$, cloudy appearance $(14.3 \%)$, presence of proteins $(10.5 \%)$ and deposits (5.7\%) were reported. (Table 2).
Table 1 Participant characteristics

\begin{tabular}{|c|c|c|}
\hline Characteristics & $\mathbf{N}$ & $\%$ \\
\hline \multicolumn{3}{|l|}{ Age (years) } \\
\hline$\leq 14$ & 1 & 1.3 \\
\hline $15-30$ & 18 & 24.0 \\
\hline $31-45$ & 20 & 26.6 \\
\hline $46-65$ & 27 & 36.0 \\
\hline$>65$ & 9 & 12.0 \\
\hline \multicolumn{3}{|l|}{ Gender } \\
\hline Male & 30 & 40.0 \\
\hline Female & 45 & 60.0 \\
\hline \multicolumn{3}{|c|}{ Origen/cities of Pernambuco state } \\
\hline Recife & 34 & 45.4 \\
\hline Jaboatão dos Guararapes & 13 & 17.3 \\
\hline Olinda & 11 & 14.7 \\
\hline Paulista & 9 & 12.0 \\
\hline Camaragibe & 2 & 2.7 \\
\hline Cabo de Santo Agostinho & 1 & 1.3 \\
\hline São Lourenço da Mata & 1 & 1.3 \\
\hline Vitória de Santo & 2 & 2.7 \\
\hline Caruaru & 1 & 1.3 \\
\hline Riacho das Almas & 1 & 1.3 \\
\hline
\end{tabular}

The mean value of cells and casts, through Addis test, was $155.43 \mathrm{E} / \mathrm{min} / \mathrm{mL}$ (minimum and maximum value of $2310 \mathrm{E} / \mathrm{min} / \mathrm{mL}$ ), mean value of red cells was $52,892 \mathrm{E} /$ $\mathrm{min} / \mathrm{mL}$ (minimum value of $0.550 \mathrm{E} / \mathrm{min} / \mathrm{mL}$ and maximum value of $291,660 \mathrm{E} / \mathrm{min} / \mathrm{mL}$ ), and mean leukocyte value was $33,058 \mathrm{E} / \mathrm{min} / \mathrm{mL}$ (minimum value of $28.4 \mathrm{E} /$ $\mathrm{min} / \mathrm{mL}$ and maximum value of $140,511 \mathrm{E} / \mathrm{min} / \mathrm{mL}$ ). Among the 57 individuals who underwent 24-h proteinuria, the majority $(61 \%)$ presented changed values, with an average value of $1372.80 \mathrm{mg} / \mathrm{dL}$ (minimum value of $0.257 \mathrm{mg} / \mathrm{dL}$ and a maximum value of $14,000 \mathrm{mg} / \mathrm{dL}$ ). Urinary lymphocytes were positive in most cases (68.3\%). Regarding the biomarkers for LF, the immunochromatographic test (ICT) was positive in $16.7 \%$ of the cases. The presence of circulating antigens OG4C3 was positive in only $7.7 \%$ of the cases and microfilaremia was positive in only $1 / 55$ of the individuals.

Among the individuals studied, 45\% (34/75) performed ultrasonography (USG) of the abdomen and/or scrotal pouch and/or lower limbs, and half (17/34) showed echographic changes. Diffuse soft tissue lower limb edema, hydrocele, scrotal pouch lymphangiectasis, unilateral renal ectasia, and bladder echoes were the most frequently described changes.

In the reported cases of pain and in relation to its topography 10 patients ( $13.3 \%$ of the sample), there was a significant difference $(\mathrm{p}<0.05)$ between the female sex (30\% of those) and male (10\%. According to Fisher's exact 
Table 2 Laboratory parameters of urinalysis and LF biomarkers in 75 individuals with Chyluria treated at the SRNF from 1996 to 2016

\begin{tabular}{|c|c|c|c|c|}
\hline Parameter & \multicolumn{2}{|c|}{ Average value } & Variation & $\mathrm{p}$ value \\
\hline \multicolumn{5}{|l|}{ Addis test } \\
\hline Leukocytes & \multicolumn{2}{|c|}{33,058} & $28.4-140,511$ & 0.3789 \\
\hline Casts & \multicolumn{2}{|c|}{155.43} & $0-2310$ & 0.479 \\
\hline Blood cells & \multicolumn{2}{|c|}{52,892} & $0.550-291,660$ & 0.476 \\
\hline \multicolumn{5}{|c|}{ Urine lymphocytes (mg/dL) } \\
\hline \multicolumn{3}{|l|}{ Present } & \multicolumn{2}{|l|}{32 (63.3\%) } \\
\hline \multicolumn{3}{|l|}{ Absent } & \multicolumn{2}{|l|}{$17(34.7 \%)$} \\
\hline \multicolumn{5}{|l|}{ Biochemistry } \\
\hline 24-h proteinuria (mg/dL) & \multicolumn{2}{|c|}{1372.80} & $0.257-14,000$ & 0.387 \\
\hline \multicolumn{2}{|l|}{ Tests } & Results & \multicolumn{2}{|c|}{$\begin{array}{l}\text { Number of reagent } \\
\text { samples (\%) }\end{array}$} \\
\hline \multicolumn{5}{|l|}{ Biomarkers } \\
\hline \multirow[t]{2}{*}{ Microfilaremia } & & Positive & \multicolumn{2}{|l|}{$1(1.8 \%)$} \\
\hline & & Negative & \multicolumn{2}{|l|}{55 (98.2\%) } \\
\hline \multirow{2}{*}{\multicolumn{2}{|c|}{$\begin{array}{l}\text { Immunochromatographic test } \\
(\mathrm{ICT})\end{array}$}} & Positive & \multicolumn{2}{|l|}{$7(16.7 \%)$} \\
\hline & & Negative & \multicolumn{2}{|l|}{$35(83.3)$} \\
\hline \multirow[t]{2}{*}{ OG4C3 } & & Positive & \multicolumn{2}{|l|}{$1(7.7 \%)$} \\
\hline & & Negative & \multicolumn{2}{|l|}{$12(92.3 \%)$} \\
\hline
\end{tabular}

test there was also a significant association $(\mathrm{p}<0.01)$ between lymphocyte count and number of erythrocytes in the urine.

\section{Discussion}

In this study, we retrospectively reviewed the medical records of 75 individuals living in an endemic area of LF. Individuals complained of chyluria. There was a slight predominance of women in the sample, while the majority of studies had a higher proportion of men [14, 21-23]. However, this may be related to the fact that women seek more medical care. The mean age of the individuals at the time of the first hospital visit was 45 years of age. In India, Tandon et al. [23] described chyluria in patients with LF in individuals aged 15-30 years [23], and this higher age range in our sample may partly reflect a delay in care.

The diagnosis of LF has been based mainly on the clinical expression of residents of endemic areas. Hydrocele and lymphedema are the main clinical manifestations, whereas chyluria is a less common presentation [24] that manifests itself through milky-color urine associated with flank pain, similar to ureteric cramps [25] and may be triggered by meals with high lipid contents. More severe cases may result in malnutrition, hypoproteinemia, immune dysfunction and hypercoagulability states $[26,27]$. Chyluria may present an unpredictable clinical course, including spontaneous remission in up to half of the individuals [28].
Chyluria may still be a manifestation of tuberculosis and deep mycoses, in addition to non-infectious causes such as traumas, post-surgical status such as partial nephrectomy and aorta-iliac by-pass, lymphatic malformations, pelvic tumors, irradiation, pregnancy and malformations such as stenosis of the thoracic duct [29]. All our patients underwent ultrasound examinations of the abdomen, and none of them had obstructive causes or the presence of tumors. However, we were not able to perform other diagnostic tests to rule out other infectious causes.

Some biomarkers have been used for the diagnosis of filarial infections and are able to detect microfilariae and/or their antigens in peripheral blood, besides the possibility of using ultrasound to identify adult worms in lymphatic vessels [30]. Among the most common diagnostic tests, the identification of microfilariae in the peripheral blood, identification of W. bancrofti antigens by an immunoenzymatic assay based on $\mathrm{Og} 4 \mathrm{C} 3$ monoclonal antibodies and immunochromatographic test (ICT) are highlighted [31-33]. The ICT card test is a fast test performed by digital capillary punctures where total blood is spread on a card impregnated with filarial antigen markers, and the result is interpreted by colorimetric reaction. Despite the easy execution of the test, a negative result is not able to exclude filarial infection as a cause of a chronic pathology, since filarial antigens eventually become undetectable in a treated infection even in a scenario of already installed lymphatic damage [34]. In the studied population, only one individual had microfilariae in the peripheral blood. Among those who underwent ICT and $\mathrm{Og} 4 \mathrm{C} 3$, only 16.7 and $7.7 \%$ presented positive results, which corroborates with other studies describing a low sensitivity of such tests in a scenario of late filarial infection and already installed filarial morbidity [35].

The analysis of urine in patients with chyluria may reveal the presence of chylomicrons and triglycerides. The quantification of these elements is the most specific and sensitive marker for diagnostic confirmation [36]. In our cases, the presence of hematuria (27.6\%), possibly due to the deposition of immunocomplexes in the basal glomerular membrane and leukocytes (21.9\%), was observed through the Addis test. There was also expression of an abnormal connection between the lymphatic system and the urinary system [37]. Urine lymphocyte screening was present in $63.3 \%$, which is compatible with data from the literature. Some studies have indicated the presence of lymphocytes in the urine as an important microscopic marker due to the formation of venolymphatic fistulas leading to an increased pressure in lymphatic vessels [38-40]. Protein concentration in the 24-h urine test presented mean values of $1372.80 \mathrm{mg} / \mathrm{dL}$, 
which may reflect a picture of nephritis by immune complex deposition. However, this was not confirmed [41].

\section{Limitations}

- The low proportion of individuals with chyluria and residents of endemic LF areas with registered protocols is a possible limitation of this study.

- We were not able to perform other diagnostic tests to rule out other infectious causes.

\section{Abbreviations}

ICT: immunochromatographic test; FIOCRUZ: Osvaldo Cruz Foundation.

\section{Authors' contributions}

All authors contributed equally. Conceptualization: PSRA, VRSJ, AS, LBCF, EB and AR. Formal analysis: PSRA, VRSJ, AS, LBCF, EB and AR. Investigation: PSRA, VRSJ, AS, LBCF, EB and AR. Writing —original draft: PSRA, VRSJ, AS, LBCF, EB and AR. Writing - review and editing: PSRA, VRSJ, AS, LBCF, EB and AR. All authors read and approved the final manuscript.

\section{Author details}

${ }^{1}$ Federal University of Pernambuco, Av. Prof. Moraes Rego 1235, Recife, Pernambuco 50670-901, Brazil. ${ }^{2}$ Instituto Aggeu Magalhaes, FIOCRUZ, Av. Prof. Moraes Rego 1235, Recife 50670-901, Brazil.

\section{Acknowledgements}

Not applicable.

\section{Availability of data and materials}

The data that support the findings of this study are made available from by the Instituto Aggeu Magalhaes.

\section{Competing interests}

The authors declare that they have no competing interests.

\section{Consent for publication}

Not applicable.

\section{Ethics approval and consent to participate}

The study was submitted and approved by the Ethics Committee of Instituto Aggeu Magalhaes for the publication of this work. A copy of the written informed consent is available for review by the Editor-in-Chief of this journal. The authors declare that the procedures followed the regulations established by the local Ethics Committee of the Instituto Aggeu Magalhaes and the Helsinki Declaration of the World Medical Association. Instituto Aggeu Magalhaes hospital gave access to confidential patient medical records to the authors and these records were anonymous.

\section{Funding}

There is no funding to report for this publication.

\section{Publisher's Note}

Springer Nature remains neutral with regard to jurisdictional claims in published maps and institutional affiliations.

Received: 11 January 2018 Accepted: 18 April 2018

Published online: 02 May 2018

\section{References}

1. Rey L. Wuchereria bancrofti e filarioses linfáticas. In: Parasitologia: Parasitos e Doenças parasitárias do homem nas Américas e na África. Guanabara Koogan. Rio de Janeiro; 2001.
2. Fontes $G$, Braun RF, Neto HF, Vieira JBF, Padilha SS, Rocha RC, Rocha EMM. Filariose linfática em Belém, Estado do Pará, Norte do Brasil e a perspectiva de eliminação. Rev Soc Bras Med Trop. 2005;38:131-6.

3. World Health Organization (WHO). Global programme to eliminate lymphatic filariasis: progress report on mass drug administration in 2007. Wkly Epidemiol Rec. 2008;83:333-48.

4. WHO (World Health Organization). Global programme to eliminate lymphatic filariasis. Progress report 2000-2009 and strategic plan 2010-2020 of the global programme to eliminate lymphatic filariasis: halfway towards eliminating lymphatic filariasis, Geneva; 2010.

5. Lahariya C, Tomar SS. How endemic countries can accelerate lymphatic filariasis elimination? An analytical review to identify strategic and programmatic interventions. J Vector Borne Dis. 2011;48(1):1.

6. WHO. Global programme to eliminate lymphatic filariasis: progress report, 2013. Geneva: World Health Organisation; 2014.

7. Modi A, Gamit S, Jesalpura BS, Kurien G, Kosambiya JK. Reaching endpoints for lymphatic filariasis elimination-results from mass drug administration and nocturnal blood surveys, South Gujarat, India. PLOS Negl Trop Dis. 2017. https://doi.org/10.1371/journal.pntd.0005476.

8. OPAS (Organização Pan Americana de Saúde). Condições de Saúde e suas tendências, vol. 1. Saúde nas Américas: Washington. OPAS. 2007; p. 62-217.

9. OMS. Organização mundial de saúde disponível em. http://www.paho. org/bra/index.php?option=com_content\&view $=$ article\&id $=4608 \% 3$ Aobrasil-avanca-eliminacao-transmissao-filariose-linfatica\&ltemid $=816$. Acessed 12 June 2017.

10. Brasil (Fundação Nacional de Saúde). Relatório da Reunião de Avaliação do Programa de Controle da Filariose Linfática, referente ao Plano de Eliminação da Filariose Linfática no Brasil, Recife-PE. Brasília, Brasil; 2000

11. MS. Ministério da Saúde. Fundação Oswaldo Cruz. http://www.invivo.fiocr uz.br/cgi/cgilua.exe/sys/start.htm?infoid=100\&sid=7. Accessed 12 June 2017.

12. CDC. Centers for disease control. Recommendations of international task force for disease eradication. Morb Mortal. 1993;42:1-38 (Weekly report).

13. Rebollo MP, Bockarie MJ. Shrinking the lymphatic filariasis map: update on diagnostic tools for mapping and transmission monitoring. Parasitology. 2014;141:1912-7.

14. Sharma S, Hemal AK. Chyluria-an overview. Int J Nephrol Urol. 2009;1:14-26.

15. Pandey AP, Ansari MS. Recurrent chyluria. Indian J Urol. 2006;22:56-8.

16. Dalela D. Issues in etiology and diagnosis making of chyluria. Indian J Urol. 2005;21:18-23.

17. Diamond E, Scahapira HE. Chyluria—a review of literature. Urology. 1985;26:427-31.

18. Brunkwall J, Simonsen O, Bergqvist D, Jonsson K, Bergentz S. Chyluria treated with renal autotransplantation: a case report. J Urol. 1990;143:793-6.

19. Yu HHY, Ngan H, Leong CH. Chyluria-a 10 year followup. BJU. 1978;50:126-33.

20. Veronesi R, Focaccia R. Tratado de infectologia. 5th ed. São Paulo: Atheneu; 2015.

21. Sunder S, Jayaraman R, Mahapatra HS, Sathi S, Venkataramanan K, Prabhu $\mathrm{K}$, et al. Analysis of case series of milky urine: a single center and departmental clinical experience with emphasis on management perspectives: a prospective observational study. Urol Ann. 2014;6(4):340-5.

22. Goyal NK, Goel A, Sankhwar S, Singh V, Ali W, Natu SM, et al. Factors affecting response to medical management in patients of filarial chyluria: a prospective study. Indian J Urol. 2014;30(1):23-7. http://www.ncbi.nlm. nih.gov/pubmed/24497677.

23. Tandon V, Singh H, Dwivedi US, Mahmood M, Singh PB. Filarial chyluria: long-term experience of a university hospital in India. Int J Urol. 2004;1 14):193-8 (discussion 199). http://www.ncbi.n/m.nih.gov/pubme d/15028095.

24. Darrad M, Basu S, Viswanathan C. Non-parasitic chyluria: a rare cause of acute urinary retention in a young Caucasian male. J Clin Urol. 2015;10(3):197-9. https://doi.org/10.1177/2051415814565204. 
25. Abeygunasekera A, Bulegoda HNH. A case of chyluria. Ceylon Med J. 2011;48(1):34.

26. Sinha RK, Ranjan N, Singh N, Amit K. Chyluria: a scourge of our region. BMJ Case Rep. 2015. https://doi.org/10.1136/bcr-2014-209188.

27. de Souza VR, de Oliveira AB, Vanderlei AM, Aroucha AQ, Duarte BP Machado AN, et al. Inherited thrombotic thrombocytopenic purpura mimicking immune thrombocytopenic purpura during pregnancy: a case report. J Med Case Rep. 2018;12(1):15.

28. Ohyama C, Saita H, Miyasato N. Spontaneous remission of chyluria. J Urol. 1979;121(3):316-7. http://linkinghub.elsevier.com/retrieve/pii/S0022 534717567671. Accessed 28 Aug 2017.

29. Graziani G, Cucchiari D, Verdesca S, Balzarini L, Montanelli A, Ponticelli C. Chyluria associated with nephrotic-range proteinuria: pathophysiology, clinical picture and therapeutic options. Nephron Clin Pract. 2011;119:c248-54.

30. Weil GJ, Ramzy RMR. Diagnostic tools for filariasis elimination programs. Trends Parasitol. 2007;23:78-82.

31. Chanteau S, Moulia-Pelat JP, Glaziou P, Nguyen NL, Luquiaud P, Plichart C, et al. Og4 3 circulating antigen: a marker of infection and adult worm burden in Wuchereria bancrofti filariasis. J Infect Dis. 1994:170(1):247-50.

32. Chesnais CB, Missamou F, Pion SDS, Bopda J, Louya F, Majewski AC, et al. Short report: semi-quantitative scoring of an immunochromatographic test for circulating filarial antigen. Am J Trop Med Hyg. 2013;89(5):916-8.

33. Zheng H, Tao Z, Fang R, Chang B, Zhang Y, Turner P. Application of immunochromatographic test for diagnosis and surveillance of bancroftian filariasis. Chin J Parasitol Parasit Dis. 1998;16:168-71.
34. Nicolas L, Plichart C, Nguyen LN, Moulia-Pelat JP. Reduction of Wuchereria bancrofti adult worm circulating antigen after annual treatments of diethylcarbamazine combined with ivermectin in French Polynesia. J Infect Dis. 1997;175(2):489-92. http://www.ncbi.nIm.nih.gov/pubme d/9203681.

35. Weil GJ, Lammie PJ, Weiss N. The ICT filariasis test: a rapid-format antigen test for diagnosis of bancroftian filariasis. Parasitol Today. 1997;13(10):401-4.

36. Singh I, Dargan P, Sharma N. Chyluria-a clinical and diagnostic stepladder algorithm with review of literature. Indian J Urol. 2004;20(2):79.

37. Gottlieb B. Chyluria due to filariasis. Proc R Soc Med. 1959;52(2):139-40.

38. Mukherjee SK, Mukherjee AK, Sen JK. Filariasis with recurrent hematuria. JAMA. 1974;230(9):1254-5. https://doi.org/10.1001/jama.1974.03240 090014006

39. Koo CG, Van Langenberg A. Chyluria. A clinical study. J R Coll Surg Edinb. 1969;14(1):31-41.

40. Akisada M, Tani S. Filarial chyluria in Japan. Radiology. 1968;90(2):311-7. https://doi.org/10.1148/90.2.311.

41. Dreyer G, Ottesen EA, Galdino E, Andrade L, Rocha A, Medeiros Z, et al. Renal abnormalities in microfilaremic patients with bancroftian filariasis. Am J Trop Med Hyg. 1992;46(6):745-51.
Ready to submit your research? Choose BMC and benefit from:

- fast, convenient online submission

- thorough peer review by experienced researchers in your field

- rapid publication on acceptance

- support for research data, including large and complex data types

- gold Open Access which fosters wider collaboration and increased citations

- maximum visibility for your research: over $100 \mathrm{M}$ website views per year

At BMC, research is always in progress.

Learn more biomedcentral.com/submissions 